\title{
Urease inhibitor (NBPT) and efficiency of single or split application of urea in wheat crop $^{1}$
}

\author{
Marcelo Curitiba Espindula2, Valterley Soares Rocha ${ }^{3}$, Moacil Alves de Souza ${ }^{3}$, \\ Marcela Campanharo ${ }^{4}$, Adérico Júnior Badaró Pimentel ${ }^{5}$
}

\begin{abstract}
NBPT (N-(n-butyl) thiophosphoric triamide), a urease inhibitor, has been reported as one of the most promising compounds to maximize urea nitrogen use in agricultural systems. The objective of this study was to evaluate the performance of irrigated wheat fertilized with urea or urea + NBPT as single or split application. The experiment was conducted from June to October 2006 in Viçosa, MG, Brazil. The experimental design followed a $2 \times 2$ factorial scheme, in which urea or urea + NBPT were combined with two modes of application: full dose at sowing $\left(60 \mathrm{~kg} \mathrm{ha}^{-1}\right)$ or split $(20 \mathrm{~kg}$ $\mathrm{ha}^{-1}$ at sowing $+40 \mathrm{~kg} \mathrm{ha}^{-1}$ as topdressing at tillering), in randomized blocks with ten replications. The split application of nitrogen fertilization does not improve the yield wheat under used conditions. The use of urease inhibitor improves the grain yield of wheat crop when urea is applied in topdressing at tillering, but its use does not promote difference when urea is applied in the furrow at planting.
\end{abstract}

Key words: Triticum aestivum L., nitrogen, ammonia volatilization.

\section{RESUMO \\ Inibidor de urease (NBPT) e a eficiência da ureia aplicada em dose única ou parcelada na cultura do trigo}

O NBPT (N-(n-butil) tiofosfórico triamida) é uma substância inibidora da urease, que se vem apresentando como das mais promissoras para a maximização do uso do nitrogênio da ureia em sistemas agrícolas. O objetivo deste estudo foi avaliar o desempenho produtivo do trigo irrigado, submetido à fertilização com ureia ou ureia+NBPT aplicadas em dose única ou parcelada. O experimento foi conduzido, de junho a outubro de 2006, em Viçosa-MG, Brasil. Seguiu-se o esquema fatorial $2 \times 2$, em que a ureia ou ureia+NBPT foram combinadas com duas formas de aplicação: dose total na semeadura $\left(60 \mathrm{~kg} \mathrm{ha}^{-1}\right)$ ou parcelada $\left(20 \mathrm{~kg} \mathrm{ha}^{-1}\right.$ na semeadura $+40 \mathrm{~kg} \mathrm{ha}^{-1}$, em cobertura, no perfilhamento). O delineamento experimental foi o de blocos ao acaso com dez repetições. Conclui-se que o parcelamento da fertilização nitrogenada não promove incremento de produtividade do trigo, sob as condições de cultivo empregadas; o uso de inibidor de urease aumenta a produtividade da cultura do trigo, quando a ureia é aplicada, em cobertura, durante o perfilhamento, mas, seu uso não promove aumento da produtividade quando a ureia é aplicada no sulco, durante a semeadura.

Palavras-chave: Triticum aestivum L., nitrogênio, volatilização de amônia.

Received: 20/09/2012; Approved:20/02/2014

${ }^{1}$ This paper is part of the first author's doctoral thesis.

${ }^{2}$ Agronomyst Engineer, Doctor of Science. Embrapa Rondônia, BR 364, Km 5.5, Zona Rural, 76815-800, Porto Velho, Rondônia, Brazil. marcelo.espindula@embrapa.br (corresponding author)

${ }^{3}$ Agronomyst Engineer, Doctor of Science. Departamento de Fitotecnia, Universidade Federal de Viçosa, Campus Viçosa, Avenida Peter Henry Rolfs, s/n, 36570-000, Viçosa, Minas Gerais, Brazil. vsrocha@ufv.br; moacil@ufv.br

${ }_{4}^{4}$ Agronomyst Engineer, Doctor of Science. Faculdades Integradas Aparício Carvalho, Rua Araras, 241, Jardim Eldorado, 78912-640, Porto Velho, Rondônia. Brazil. marcelacampanharo@gmail.com

${ }_{5}^{5}$ Agronomyst Engineer, Master of Science. Departamento de Fitotecnia, Universidade Federal de Viçosa, Campus Viçosa, Avenida Peter Henry Rolfs, s/n, 36570-000, Viçosa, Minas Gerais, Brazil. adericojr@yahoo.com.br 


\section{INTRODUCTION}

Several studies have been conducted to evaluate the correct time of nitrogen fertilization on wheat crop under Brazilian tropical conditions (Silva et al., 2008; Megda et al., 2009; Espindula et al., 2010; Hastenpflug et al., 2011; Teixeira Filho et al., 2011 Espindula et al., 2013). These studies take into account the application of nitrogen fertilizer at sowing and topdressing and suggest that $\mathrm{N}$ application just at sowing is enough to provide $\mathrm{N}$ during crop cycle. Teixeira Filho et al. (2011) suggest that nitrogen application totally at sowing is feasible, as well as is the traditional application at sowing and in top dressing, for the wheat cultivars irrigated under no till, cropped in a region of low altitude.

For application in the sowing, fertilizer is incorporated into the soil and volatilization of ammonia $\left(\mathrm{NH}_{3}\right)$ is reduced (Da Ros et al., 2005). However, in most cases, the amount of $\mathrm{N}$ needed by culture cannot be applied just during sowing, in this cases, is necessary apply fertilizers in topdressing during development of the plants. In topdressing, as commonly fertilizer is not incorporated, $\mathrm{N}$ is subject to volatilization losses (Costa et al., 2003).

Urea is the fertilizer that has had more problems with the topdress soil due to $\mathrm{N}$ losses through volatilization of $\mathrm{NH}_{3}$ (Martha Jr. et al., 2004, Duarte et al., 2007, Werneck et al., 2012; Nascimento et al., 2013). Nevertheless, this source is considered one of the most important due to its relative low cost, high water solubility and good absorption of the products of its hydrolysis by plants.

Many researchers have worked in order to minimize volatilization of $\mathrm{NH}_{3}$ from urea fertilization (Costa et al. 2003; Cantarella et al., 2008, Chien et al., 2009, Paiva et al., 2012, Stafanato et al., 2013). Alternatives include adequacy of the application time of N (Da Ros et al., 2005), management of soil moisture (Duarte et al., 2007), a mixture of urea with other fertilizers with acid characteristics, like boric acid, in order to manage the soil chemical characteristics (Vitti et al., 2007), and the use of urea coated with urease inhibitors (Chien et al., 2009).

Urease inhibitors are substances that reduce the rate of hydrolysis of urea - $\mathrm{CO}\left(\mathrm{NH}_{2}\right)_{2}$, which allows for greater percolation of urea in the soil profile, reducing the concentration of $\mathrm{NH}_{3}$ on the soil surface which therefore reduces the volatilization $\mathrm{NH}_{3}$ (Malhi et al., 2001). Among the inhibitors of urease currently researched, $\mathrm{N}$-(n-butyl) thiophosphoric triamide (NBPT) stands out as one of the most promising (Krajewska, 2009).

The NBPT can be a viable alternative to minimize volatilization of $\mathrm{NH}_{3}$ (Malhi et al., 2001), but its effectiveness has not been proven for most crops and conditions in Brazil. Therefore, the aim of this study was to evaluate the performance of wheat 'Pioneiro' (Triticum aestivum L.) subjected to fertilization with urea or urea + NBPT, single or split applied.

\section{MATERIAL AND METHODS}

The experiment was conducted at the Viçosa-MG $\left(20^{\circ}\right.$ $45^{\prime} \mathrm{S}$ and $42^{\circ} 51^{\prime} \mathrm{W}$, altitude 650 meters) in the period from June to October 2006. Daily data of maximum, average and minimum temperature; relative humidity; wind speed and rainfall during the experimental period were obtained from the climatological station of the Agricultural Engineering Department at UFV (Figure 1).

The soil of the experiment area was classified as "Argissolo Vermelho Amarelo" (Embrapa, 2006) that has been cultivated with soybean (summer) and wheat (winter) in the four last years. The chemical characteristics of this soil layer were determined from zero to $20 \mathrm{~cm}$ (Table 1).

Soil preparation was done through a conventional tillage and fertilization was performed sowing with $80 \mathrm{~kg}$ $\mathrm{P}_{2} \mathrm{O}_{5} \mathrm{ha}^{-1}$ as superphosphate simple and $40 \mathrm{~kg} \mathrm{ha}^{-1} \mathrm{~K}_{2} \mathrm{O}$, as $\mathrm{KCl}$ (Embrapa, 2005). Wheat seeds 'Pioneiro' were sown at a density of 350 seeds useful per $\mathrm{m}^{2}$.

The experiment was conducted in $2 \times 2$ factorial design, in which urea or urea + NBPT (N-(n-butyl) thiophosphoric triamide) $\left(\right.$ Agrotain $\left.^{\circledR}\right)$ were combined with two application methods: 1) Unique shape: total dose, $60 \mathrm{~kg} \mathrm{ha}^{-1}$ of $\mathrm{N}$, during sowing or 2) Split shape: $20 \mathrm{~kg} \mathrm{ha}^{-1}$ of $\mathrm{N}$ at sowing and $40 \mathrm{~kg} \mathrm{ha}^{-1}$ in topdressing (Embrapa, 2005). The design was randomized blocks with ten replications. Each plot consisted of seven lines with five meters long spaced at $0.20 \mathrm{~m}$. The area of the plot, $2.4 \mathrm{~m}^{2}$, was formed by the three central lines being eliminated $0.5 \mathrm{~m}$ at both ends of the lines.

Fertilization topdressing for treatments that received fertilizer split was performed at 25 days after seedling emergence, when plants were at tillering stage. The experiment was irrigated seven days after fertilization topdressing, using sprinkler irrigation, applying $20 \mathrm{~mm}$ of water depth.

The contents of $\mathrm{N}$ in the shoots at anthesis, flag leaf at flowering plants and harvested grains were determined. The $\mathrm{N}$ content at anthesis was determined in shoots of 10 plants taken at random in the plot. On flag leaf, it was determined on 15 flag leaves taken at random in the plot. The $\mathrm{N}$ content in grains was determined in samples obtained by seed separator, withdrawing the amount of grain harvested in the plot. The $\mathrm{N}$ content was obtained by the Kjeldahl method.

In the physiologic maturation phase of the grains it was obtained the following traits: plant height, thousand grain weight, hectoliter mass, number of grains per spike, number of spikes per square meter, shoot dry mass, grain yield and harvest index. 
Plant height was determined by the assessment of fifteen plants per plot, measuring the girth to the apex of the ear and excluding the awns. The thousand grain weight was determined by averaging the count of eight repetitions with 100 grains each. The hectoliter mass was determined using specific scales, from grain harvested from plants of the plot. The number of grains per spike, shoot dry mass and harvest index (ratio of grain yield with zero percent moisture and shoot dry mass) were measured in 100 stems collected in sequence in the central row of the plot. The number of spikes per square meter was determined by direct counting in three segments of a subway line, picked randomly in the plot. The grain yield was determined from grain harvested from plants of the useful plot, $2.4 \mathrm{~m}^{2}$. These grains were dried to $13 \%$ moisture, and the grain yield was converted to $\mathrm{kg} \mathrm{ha}^{-1}$.

Data were subjected to analysis of variance and comparisons between means by Tukey test $(\mathrm{p}<0.05)$ using
Genes statistical program (Cruz, 2006). We admitted the factorial interaction as a significant factor for all the evaluated traits. Therefore, we consider the unfolder factors for the application of the Tukey test.

\section{RESULTS AND DISCUSSION}

The treatments did not influence the $\mathrm{N}$ concentration of whole plant at anthesis (Figure 2a). The result may be related to the dilution effect of $\mathrm{N}$, as will be discussed later. However, the $\mathrm{N}$ concentration in flag leaves of plants fertilized with urea in a piecemeal manner was less than those fed urea in a single rate or those fed urea + NBPT split (Figure 2b).

The results to $\mathrm{N}$ concentration in flag leaves suggests that the $\mathrm{N}$ recovery was lower when the fertilizer was applied in top dressing, a fact which is related to the loss of ammonia from urea. This result differs from those
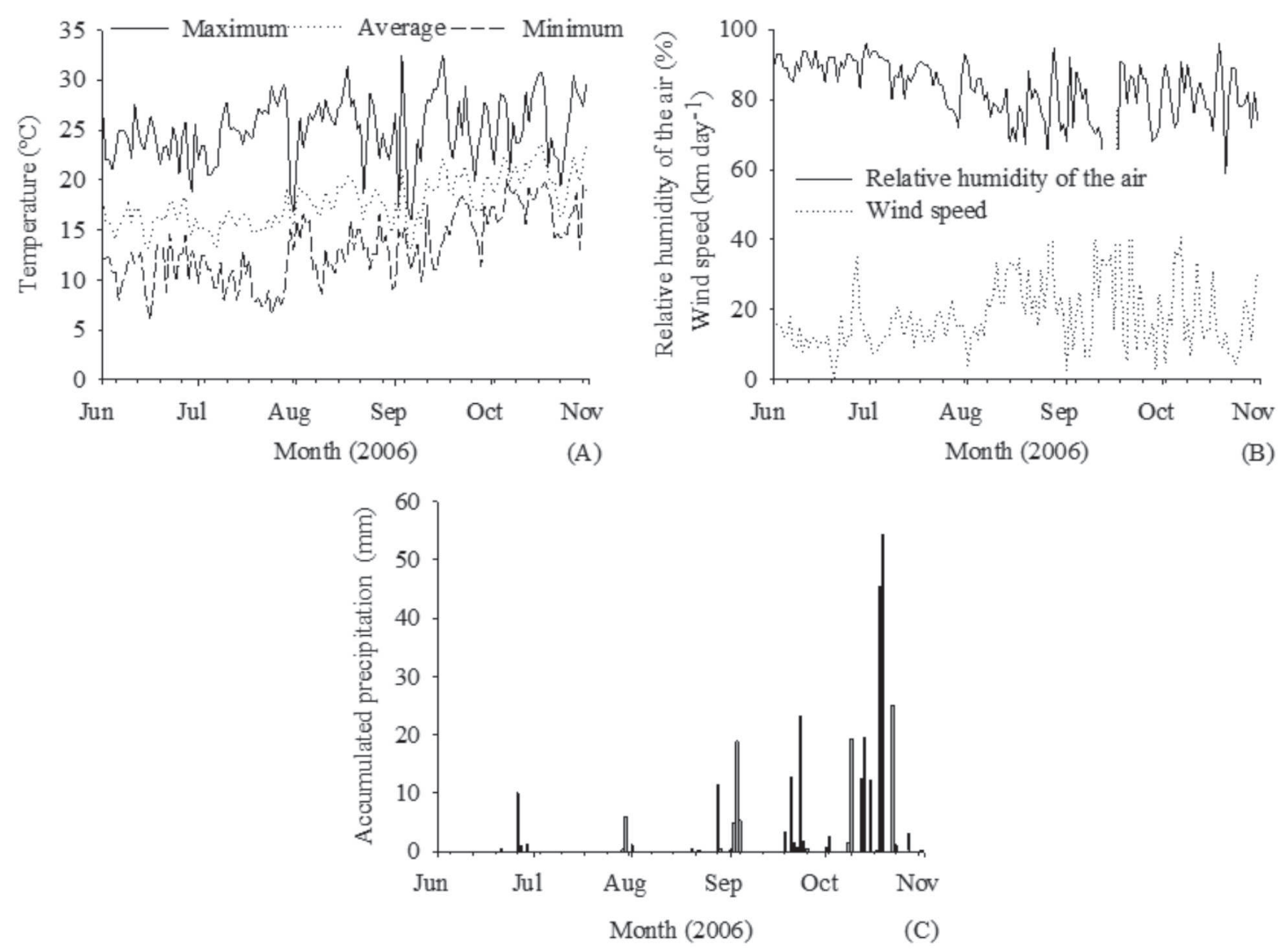

Figure 1. Temperature: maximum, average and minimum (a), relative humidity and wind speed (b) and accumulated precipitation (c), verified in Viçosa, MG, from June to October 2006.

Table 1. Chemical characteristics of the used Argissolo Vermelho Amarelo. Viçosa, MG, Brazil. 2006

\begin{tabular}{|c|c|c|c|c|c|c|c|c|c|c|c|}
\hline pH* & $\mathbf{P}$ & $\mathbf{K}$ & $\mathrm{Ca}^{2+}$ & $\mathbf{M g}^{2+}$ & $\mathbf{A l}^{3+}$ & $\mathbf{H}+\mathbf{A l}$ & SB & CEC(t) & CEC(T) & \multirow{2}{*}{$\begin{array}{l}\text { BS } \\
(\%) \\
\end{array}$} & \multirow{2}{*}{$\frac{\mathrm{OM}}{\mathrm{g} \mathrm{kg}^{-1}}$} \\
\hline $\mathrm{H}_{2} \mathrm{O}$ & \multicolumn{2}{|c|}{$\mathrm{mg} \mathrm{dm}^{-3}$} & \multicolumn{7}{|c|}{$\mathrm{cmol}_{\mathrm{c}} \mathbf{d m}^{-3}$} & & \\
\hline 5.6 & 2.9 & 05 & 2.3 & 0.5 & 0.0 & 3.47 & 3.07 & 3.07 & 6.54 & 47 & 17.3 \\
\hline
\end{tabular}

* $\mathrm{pH}\left(\mathrm{H}_{2} \mathrm{O}-1: 2.5\right), \mathrm{Ca}^{2+}, \mathrm{Mg}^{2+}$ and $\mathrm{Al}^{3+}$ : extractor $\mathrm{KCl} 1 \mathrm{~mol} \mathrm{dm}^{-3}, \mathrm{P}$ and $\mathrm{K}, \mathrm{Mehlich}^{-1}, \mathrm{H}+\mathrm{Al}$ : Calcium Acetate extractor $0.5 \mathrm{~mol} \mathrm{dm}^{-3}$ to $\mathrm{pH}$ 7.0. SB: Sum of bases; CEC(t): effective cation exchange capacity; CEC(T): cation exchange capacity at pH 7.0; $\mathrm{BS}$ : base saturation; OM: organic matter 
reported for two years of observation in wheat, where there were no differences between the forms of application or split application increased the concentration of $\mathrm{N}$ in flag leaf (Megda et al., 2009). However, these authors used the incorporation by irrigation immediately after fertilization top dressing.

Plants that received urea + NBPT in topdressing had higher $\mathrm{N}$ concentration in grain than those who received urea (Figure 2c). The results suggest that urea + NBPT when applied to surface provided greater recovery of $\mathrm{N}$ by wheat plants which resulted in higher nutrient content in grains, as suggests Marino et al. (2011). The NBPT reduces the volatilization of $\mathrm{NH}_{3}$ through the retardation of urea hydrolysis (Cantarella et al., 2008) and thus it is believed that this delay was sufficient to reduce losses to the incorporation by irrigation, for seven days after fertilization coverage.

The split application of urea + NBPT also increased the concentration of $\mathrm{N}$ grains in the single application. There was no difference between the forms of application for this feature, when urea was applied (Figure 2c). The similarity between the forms of application can be attributed to the dilution effect, since the grain yield was higher when $\mathrm{N}$ was applied in single dose. On the other hand, for the urea treatment NBPT, although no differences were found in the $\mathrm{N}$ concentration of flag leaf and whole plant, it is believed that the greatest concentration of $\mathrm{N}$ in the grains is related to higher harvest index for plants receiving split fertilization (Figure 3). That is, compensatory effect occurred, that means that the plants which received $\mathrm{N}$ at the tillering beginning produced fewer vegetative mass in relation to grain production, and fewer grains per ear and per unit area and thus, were-able to concentrate more protein $(\mathrm{N})$ in their grain. This effect is similar to those reported for wheat in the Mediterranean region where the greatest amount of grain produced was related to lower nitrogen concentration in grains (Acreche \& Slafer, 2009). Reinforcing such indication, the wheat plants that received a full rate of $\mathrm{N}$ at sowing had a lower harvest index and $\mathrm{N}$ concentration in grain that plants receiving split rate (López-Bellido et al., 2005).

The height of plants receiving all $\mathrm{N}$ at sowing was higher than the height of those who received fractionated $\mathrm{N}$ in both treatments, urea or urea + NBPT. There was no difference between the treatments with urea and urea + NBPT for this feature (Figure 3a). The smaller plants height receiving $\mathrm{N}$ splitted is different to results found with wheat in the same place (Espindula et al., 2010). However, in that study, plants were fertilized with ammonium sulfate, source subject to small losses volatilization. This behavior occurs because the availability of $\mathrm{N}$ in the initial stages of grasses development promotes greater plant growth, since in these phases, the largest division and cell expansion occurs (Schroder et al., 2000). In the advanced stages of plant
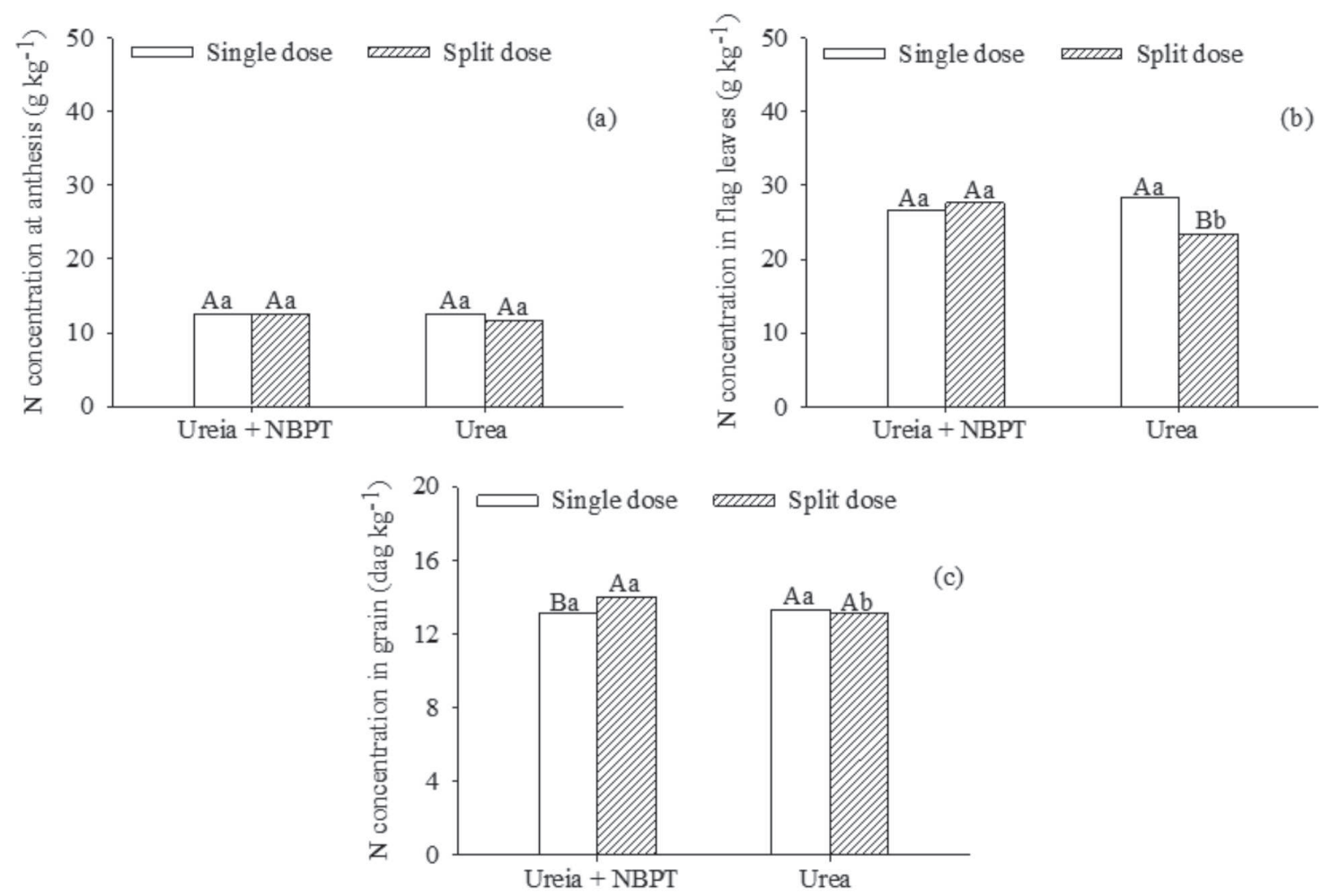

Figure 2. N concentration in tissues of wheat plants 'Pioneiro' at anthesis (whole plant) (a), flag leaf of plants at anthesis (b) and in gain (c) subjected to urea or urea + NBPT applied in a single dose or split. Means followed the same uppercase letter within the treatment urea or urea + NBPT, and the same letter within the same application form, do not differ by Tukey test $(\mathrm{p}<0.05)$. 
development, $\mathrm{N}$ contributes to the grain formation and grain filling, and especially to the production of protein (Marino et al., 2011).

Thousand grain mass (TGM) and hectoliter mass (HM) varied significantly only when $\mathrm{N}$ was split. In this form of application, plants receiving urea + NBPT had higher TGM and HM than those who received urea (Figures $3 \mathrm{~b}$ and
$3 c)$. These results were due to lower capacity for grain filling of plants receiving urea, as evidenced by the lower $\mathrm{N}$ concentration in flag leaf of these plants (Figure $2 \mathrm{~b}$ ).

The number of kernels per ear was not significantly influenced by treatments proposed (Figure 3d). However, in both form of $\mathrm{N}$ application, the urea+NBPT promoted a larger number of spikes per $\mathrm{m}^{2}$ that urea. For this feature
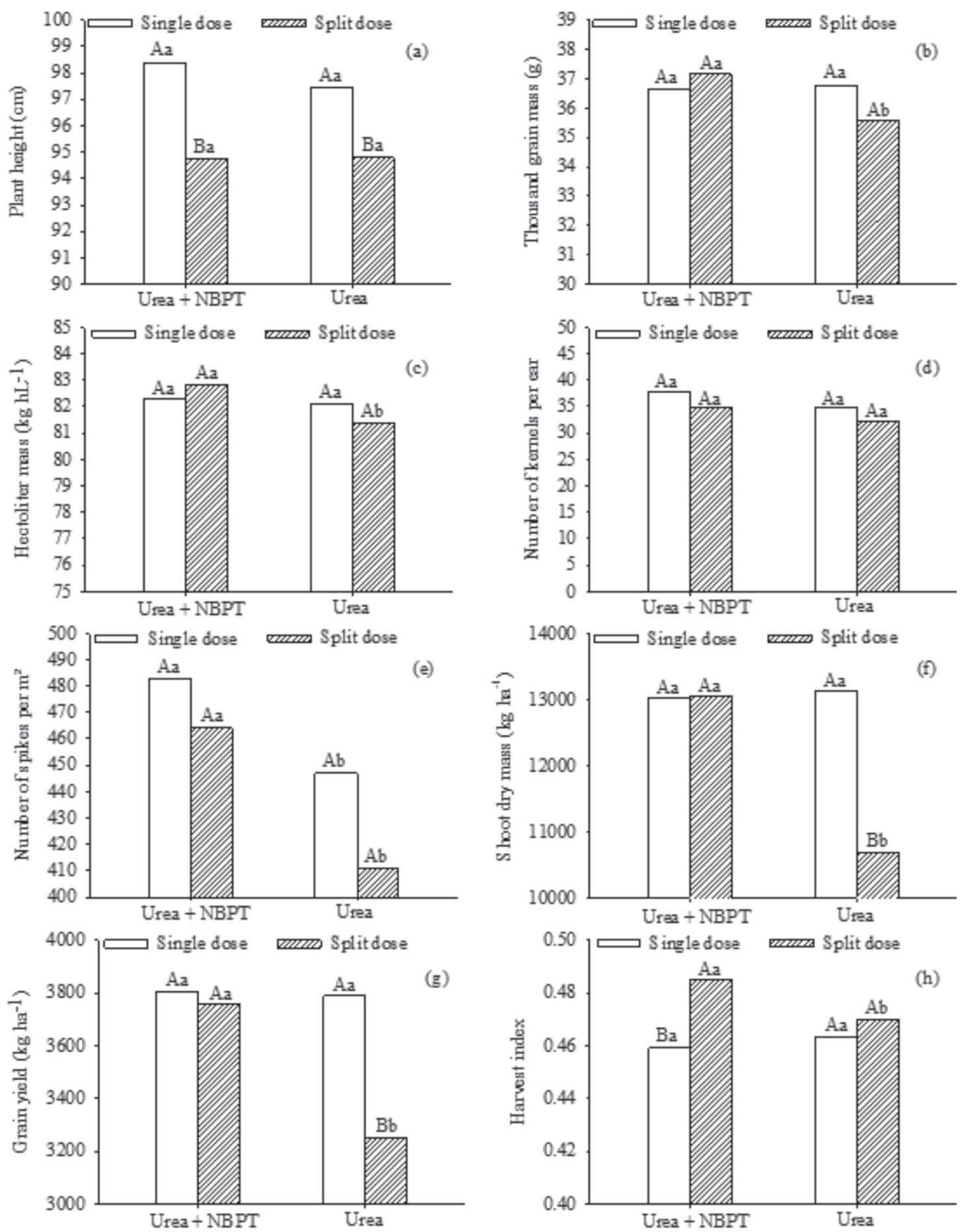

Figure 3. Agronomic characteristics of wheat 'Pioneiro' subjected to urea or urea + NBPT applied in single or divided. Means followed by the same uppercase letter within the treatment urea or urea + NBPT, and the same letter within the same application form, does not differ by Tukey test $(\mathrm{p}<0.05)$. 
there was no significant difference between single and split fertilization of the same fertilizer (Figure 3e). The largest number of spikes per $\mathrm{m}^{2}$ obtained with urea NBPT is related to lower volatilization of $\mathrm{NH}_{3}$ promoted by this treatment (Cantarella et al., 2008), which had smaller losses through volatilization, greater availability of $\mathrm{N}$ in the soil and, consequently, lower tiller abortion.

The split application of urea resulted in lower values of shoot dry mass (SDM) and grain yield than urea in a single dose and urea + NBPT splitted. These characteristics were similar between urea and urea + NBPT, under single dose, and between the forms of application of urea + NBPT (Figures $3 f$ and $3 g$ ). The similarities between application methods corroborate those reported in the literature (López-Bellido et al., 2005) and are related to the short period of time between sowing and topdressing. The similarities between urea and urea + NBPT in the single application form, suggest that for these conditions, the use of NBPT does not bring benefit.

The lower values of SDM and yield of plants receiving split urea suggest that under these conditions, the $\mathrm{N}$ utilization is compromised. The results are opposite to those reported wheat under Brazilian tropical conditions, where the split caused the same agronomic performance of plants (Silva et al., 2008; Espindula et al., 2010; Teixeira Filho et al., 2011), or greater yield of grains (Megda et al., 2009). However, in present study, urea remained without incorporation during seven days under favorable conditions to volatilization. Thus, it is believed that the lower performance of this treatment is due to higher $\mathrm{N}$ losses through volatilization of $\mathrm{NH}_{3}$.

The harvest index for plants receiving urea + NBPT at split rate was higher than that who received the same treatment at full rate at sowing (Figure $3 \mathrm{~h}$ ). This behavior suggests smaller vegetative plant mass, as suggested by smaller plant height (Figure 3a).

The application form did not influence the harvest index of plants receiving urea, similarly to results reported by Espindula et al. (2010). However, the split dose of urea resulted in a smaller harvest index than urea + NBPT split (Figure 3h). For both comparisons, the results again suggest lower recovery of $\mathrm{N}$ when urea is applied in the split form.

\section{CONCLUSIONS}

The split application of nitrogen fertilization does not improve the yield of wheat under the conditions used.

The use of urease inhibitor improves the grain yield of wheat crop when urea is applied in topdressing at tillering, but its use does not promote difference when urea is applied in the furrow at planting.

\section{ACKNOWLEDGEMENTS}

The authors would like to thank the "Fundação de Amparo à Pesquisa do Estado de Minas Gerais" (FAPEMIG) and "Conselho Nacional de Desenvolvimento Científico e Tecnológico" (CNPq) for the financial support and grants as well as to Fertipar Southeast Agricultural Fertilizers and Correction Ltd. and AGROTAIN International LLC, for their support.

\section{REFERENCES}

Acreche MM \& Slafer GA (2009) Variation of grain nitrogen content in relation with grain yield in old and modern Spanish wheat grown under a wide range of agronomic conditions in a Mediterranean region. Journal of Agricultural Science, 147:657667.

Cantarella H, Trivelin PCO, Contin TLM, Dias FLF, Rossetto R, Marcelino R, Coimbra RB \& Quaggio JA (2008) Ammonia volatilization from urease inhibitor-treated urea applied to sugarcane trash blankets. Scientia Agricola, 65:397-401.

Chien SH, Prochnow LI \& Cantarella H (2009) Recent developments of fertilizer production and use to improve nutrient efficiency and minimize environmental impacts. Advances in Agronomy, 102:267-322.

Costa MCG, Vitti GC \& Cantarella H (2003) Volatilização de N$\mathrm{NH}_{3}$ de fontes nitrogenadas em cana-de-açúcar colhida sem despalha a fogo. Revista Brasileira de Ciência do Solo, 27:631637.

Cruz CD (2006) Programa Genes: Estatística experimental e matrizes. Viçosa, Editora UFV. 285p.

Da Ros CO, Aita C \& Giacomini SJ (2005) Volatilização de amônia com aplicação de uréia na superfície do solo, no sistema plantio direto. Ciência Rural, 35:799-805.

Duarte FM, Pocojeski E, Silva LS, Graupe FA \& Britzke D (2007) Perdas de nitrogênio por volatilização de amônia com aplicação de uréia em solo de várzea com diferentes níveis de umidade. Ciência Rural, 37:705-711.

Embrapa - Empresa Brasileira de Pesquisa Agropecuária (2006) Sistema brasileiro de classificação de solos. $2^{a}$ ed. Rio de Janeiro, Embrapa. 306p.

Embrapa - Empresa Brasileira de Pesquisa Agropecuária (2005) Informações técnicas para a cultura de trigo na Região do Brasil Central: safras 2005 e 2006. In: Reunião da Comissão Centro Brasileira de Pesquisa de Trigo, Goiânia. 82p. (Documentos/ Embrapa Arroz e feijão, ISSN 1516-7518;173).

Espindula MC, Rocha VS, Souza MA, Campanharo M \& Paula GS (2013) Rates of urea with or without urease inhibitor for topdressing wheat. Chilean Journal of Agricultural Research, 73:160-167.

Espindula MC, Rocha VS, Souza MA, Grossi JAS \& Souza LT (2010) Doses e formas de aplicação de nitrogênio no desenvolvimento e produção da cultura do trigo. Ciência e Agrotecnologia, 34:1404-1411.

Hastenpflug M, Martin TN, Braida JA, Barbosa DK, Zielinski RP \& Refatti R (2011) Grain yield of dual-purpose wheat cultivars as affected by nitrogen and cuttings. Bragantia, 70:819-824.

Krajewska B (2009) Ureases I. Functional, catalyctic and kinetic properties: A review. Journal of Molecular Catalysis B: Enzimatic, 59:09-21. 
López-Bellido L, Lopez-Bellido RJ \& Redondo R (2005) Nitrogen efficiency in wheat under rainfed Mediterranean conditions as affected by split nitrogen application. Field Crops Research, 94:86-97

Malhi SS, Grant CA, Johnston AM \& Gill KS (2001) Nitrogen fertilization management for no-till cereal production in the Canadian Great Plains: a review. Soil \& Tillage Research, 60:101122

Martha Jr GB, Corsi M, Trivelin PCO, Vilela L, Pinto TLF, Teixeira GM, Manzoni CS \& Barioni LG (2004) Perda de amônia por volatilização em pastagem de capim-tanzânia adubada com ureia no verão. Revista Brasileira de Zootecnia, 33:2240-2247.

Marino S, Tognetti R \& Alvino A (2011) Effects of varying nitrogen fertilization on crop yield and grain quality of emmer grown in a typical Mediterranean environment in central Italy. European Journal Agronomy, 34:172-180.

Megda MM, Buzetti S, Andreotti M, Teixeira Filho MMC \& Vieira MX (2009) Resposta de cultivares de trigo ao nitrogênio em relação às fontes e épocas de aplicação sob plantio direto e irrigação por aspersão. Ciência e Agrotecnolgia, 33:1055-1060.

Nascimento CAC, Vitti GC, Faria LA, Luz PHC \& Mendes FL (2013) Ammonia volatilization from coated urea forms. Revista Brasileira de Ciência do Solo, 37:1057-1063.

Paiva DM, Cantarutti RB, Guimarães GGF \& Silva IR (2012) Urea coated with oxidized charcoal reduces ammonia volatilization. Revista Brasileira de Ciência do Solo, 36:1221-1229.
Schroder JJ, Neeteson JJ, Oenema O \& Struik PC (2000) Does the crop or the soil indicate how to save nitrogen in maize production?: Reviewing the state of the art. Field Crops Research, 66:151-164.

Silva SA, Arf O, Buzetti S \& Silva MG (2008) Fontes e épocas de aplicação de nitrogênio em trigo em sistema plantio direto no cerrado. Revista Brasileira de Ciência do Solo, 32:2717-2722.

Stafanato JB, Goulart RS, Zonta E, Lima E, Mazur N, Pereira CG \& Souza HN (2013) Volatilização de amônia oriunda de ureia pastilhada com micronutrientes em ambiente controlado. $\mathrm{Re}$ vista Brasileira de Ciência do Solo, 37:726-732.

Teixeira Filho MCM, Buzetti S, Andreotti M, Arf O \& Sá ME (2011) Application times, sources and doses of nitrogen on wheat cultivars under no till in the Cerrado region. Ciência Rural, 41:1375-1382.

Vitti AC, Trivelin PCO, Gava GJC, Franco HCJ, Bologna IR \& Faroni CE (2007) Produtividade da cana-de-açúcar relacionada à localização de adubos nitrogenados aplicados sobre os resíduos culturais em canavial sem queima. Revista Brasileira Ciência do Solo, 31:491-498.

Werneck CG, Breda FA, Zonta E, Lima E, Polidoro JC, Balieiro FC \& Bernardi ACC (2012) Volatilização de amônia proveniente de ureia com zeólita natural. Pesquisa Agropecuária brasileira, 47:466-470. 